\title{
Analysis of a U.S. Summer School Program and Implications for Remedial English Education
}

\author{
Chin-Wen Chien \\ Department of English Instruction, National Hsinchu University of Education \\ No 521, Nando Road, Hsinchu City 330, Taiwan \\ Tel: 886-3-5213132Ｅ-mail: chinwenc@ms24.hinet.net
}

\begin{abstract}
Received: January 24, 2013 Accepted: February 3, 2013 Published: February 4, 2013
doi:10.5296/ijele.v1i1.3212 URL: http://dx.doi.org/10.5296/ijele.vli1.3212
\end{abstract}

\begin{abstract}
Disadvantaged students such as English language learners (ELLs) need additional education and support to help them keep up with their English speaking peers. A summer school program was designed and provided for ELLs in a school district in a US northwest city in 2010 and aimed to bridge the achievement gap.

This study focuses on the implementation and instruction of a summer school program in a school district in a city in the US northwest. Based on the data analysis of interviews, documents, and classroom observations, three major findings were made: the unclear goals of the summer school, the limited information the teachers had about the ELLs, and varying teaching activities and language foci. Three suggestions about how to effectively implement summer school classes as elementary school remedial English education are provided.
\end{abstract}

Keywords: English language learners (ELLs), goals, language foci, remedial education, student teacher, summer school, remedial education

\section{Introduction}

In the United States, out of every ten children in K-12 schools, four are children of color and two come from homes where languages other than English are spoken (U.S. Department of Education, National Center for Education Statistics, 2006). Nearly one in four (23 percent) of a northwest city's public school district students were English language learners (ELLs) in 2005 and 2006 (Council of the Great City Schools, 2008). Many of these students are at risk of failure due to poverty, limited English proficiency, and race, or cultural and linguistic diversity, and therefore require specific instructional strategies designed to meet their needs.

Some ELLs with little or no proficiency in English struggle to keep up with their 
English-speaking peers. District ELL students' test scores are also far worse than those of their English-proficient peers. While 61 percent of all district fourth graders were at or above math proficiency levels on the Washington Assessment of Student Learning (WASL) tests in 2007, only 22 percent of ELLs reached the proficiency level. In reading, 77 percent of all students were at or above the proficiency level on the WASL in 2007, compared to only 41 percent of fourth grade ELLs. The percentage of ELLs reaching proficiency levels in reading in 2007 reflects only a 2 percent improvement since 2004. Across the district, 12 elementary schools with ELL support programs also failed to make Adequate Yearly Progress (AYP) in 2006-07 (Council of the Great City Schools, 2008). A summer school program was designed and provided for these students in 2010 and aimed to bridge the achievement gap.

This study focuses on the implementation and instruction of a summer school program in a school district in a city in the US northwest. The major data in this study include classroom observations, interviews, and documentation. This study addresses the following questions. First, what were the goals of this summer school program? Second, what language foci were covered? Third, what teaching strategies and methods were used? Fourth, what kinds of teaching and supplementary materials were used? Fifth, what challenges did student teachers face in the program? Based on the answers to these questions, suggestions for effective implementation of a summer school program and some implications for remedial education will then be provided.

\section{Literature Review}

Summer learning loss, when students aren't attending school, equaled at least one month of instruction, particularly in math, reading and spelling, because these skills involved in these subjects require repeated practice (Cooper, Charlton, Valentine, Muhlenbruck, \& Borman, 2000). Therefore, courses offered in summer school are mainly in reading or literacy, language arts, and math. Most of the studies showed that summer school programs had a significant effect upon students' reading, language, and math (Ajwani, 2006; Ashdown \& Simic, 2000; Luftig, 2003; Moore \& Wade, 1998). Borman (2001) claims that a focus on reading instruction for disadvantaged children will be most productive if the goal of summer programs is to narrow the achievement gap and improve educational equality. However, if the goal is to prevent significant learning losses, the focus should be on math instruction. After a literature review, Cooper et al (2000) suggest that summer school should focus on reading and math. In this study, I mainly focus on the reading or literacy, due to my intentional focus on English instruction in Taiwan.

The Southern Regional Education Board (2002) lists seven recommendations. This study will focus on three of these recommendations as follows: "Summer school programs should meet clear standards for quality, program length, and scheduling," "Summer school programs should respond to individual needs through the use of innovative and creative teaching strategies," and "Summer school programs should put priority on student mastery of reading and math skills."

Ziegler's (2000) study concluded that in-service training on summer school objectives, procedures, and curriculum reduced anxiety among teachers and staff, and furthermore that 
the success of summer school relies on the communication nurtured by the school between students, parents, staff, and teachers. Ziegler's findings also accord with one of the Southern Regional Education Board (2002) recommendations that "Summer school programs should employ teachers who have specialized training or proven ability to help struggling students."

A few studies addressed the importance of a teacher orientation program and of providing the details of the of students' academic background to effectively equip teachers with expertise in remedial education.

\section{Method}

The major data in this study include classroom observation, interview, and documentation. The first type of data is documents, which are the elicitation of themes or content in a body of written or visual media (Hammersley \& Atkinson, 1983; LeCompte \& Schensul, 1999). For this purpose, copies were made of the summer school program and handouts.

Semistructured interviews were used in this study in order to explore issues, probe for and follow up on the responses and to allow for interaction (Blaikie, 2000; Flick, 1998; Hitchcock $\&$ Huges, 1989). An interview protocol was used in this study. The 30-60 minute interviews, conducted on the last week of the practicum, aimed to discover the participants' education and language background, their teaching philosophies, and their challenges and concerns regarding the summer school program.

Observation is the most natural way of collecting data (Bartels, 2005; Richards \& Morse, 2007). Seven classroom observations were conducted for this study: three for Phoebe's class, one for John's class, and three for Yolanda's class. The researcher then organized the data into more abstract units of information or themes for analysis (Creswell, 2009; Hatch 2006; LeCompte \& Schensul, 1999; Marshall \& Rossman, 2006).

Table 1. Participants' details

\begin{tabular}{|l|l|l|l|}
\hline & Yolanda & Phoebe & John \\
\hline Education & M.A. in education & B.A. in Sociology & $\begin{array}{l}\text { B.A. in Sociology, } \\
\text { Special education }\end{array}$ \\
\hline $\begin{array}{l}\text { Working } \\
\text { experience }\end{array}$ & $\begin{array}{l}\text { Student teaching } \\
\text { Part-time ELL teacher }\end{array}$ & Literacy tutor & Student teaching \\
\hline Language & English, Korean & English, Spanish & English, Spanish \\
\hline Grade level & First grade & Fourth and fifth & Second grade \\
\hline
\end{tabular}

The participants in this study (see Table 1) were three student teachers who completed their elementary school teacher certification and did their student teaching in the academic year 2009. They did their practicum in summer in order to obtain the ELL endorsement certification offered by their university. These three participants are all bilingual. While Phoebe and John are native English speakers and are fluent in Spanish, Yolanda is a Korean American and speaks both English and Korean. Yolanda has a master's degree in education, John has a bachelor's degree majoring in sociology and minoring in special education, whilst Phoebe majored in sociology at university. Yolanda had worked as a part-time ELL teacher in 
another school district and Phoebe had worked as a literacy tutor after graduation. For the summer practicum Yolanda and John worked at a lower grade level and Phoebe worked at the middle and upper elementary school grade level.

\section{Analysis}

The analysis focuses on the goals and language foci, teaching strategies and methods, teaching and supplementary materials, and challenges student teachers faced in this summer school program.

\subsection{Goals and Language Foci}

The alphabet and phonics were the main language foci in the classes taught by Yolanda and John. The first example is Yolanda's instruction on [kw] sound associated with the letters $q u$. Yolanda taught the sound of these letters by showing a picture of a quarter and asking students to pronounce the initial sound. She also asked students to come up with words that begin with the same sound. Several students responded and yelled out the word queen.

Example 1: Yolanda's instruction on the sound of the letters $q u$

Yolanda: (Shows a flashcard of a quarter to Ss.) Do you know what it is?

S1: Coin

\section{S2: Quarter}

Yolanda: We pronounce it as [kw].

Ss: $[\mathrm{kw}]$

Yolanda: What other words do you begin with $[\mathrm{kw}]$ ?

Ss: Queen

Yolanda: Good job. Now you hold this card.

Example 2 shows how John taught students the concept of rhyming. He first asked students what these two words Sam and ham have in common? However, no student responded. Instead one student asked John "what is "rhyme?" John explained the meaning of rhyme and checked if students understood the meaning by asking them if Sam and ham have the same sound. Students responded "yes."

Example 2: John's instruction on rhyme

John: What are the same about "Sam" and "ham"?

John: "Sam" and "ham" rhyme. What does "rhyme" mean?

Ss: (No response)

S1: What is "rhyme"?

John: Rhyme means two words have the same sound like "Sam" and "ham." Do they have 
the same sound?

Ss: Yes.

Reading, writing, and task-based activities were the major focuses in Phoebe's class. For the task-based activities, on July 19, 2010, students made a community poster by cutting pictures from magazines and writing captions on them. On July 20 and 21, students were divided into two groups, made their own paper puppets, read through the lines, and put on a puppet show based on a book they had read recently. For a writing activity, students were given ten minutes in free writing on a topic such as 'my family members'. Phoebe also did a reading circle. She pointed to the author on the cover first before leading the students in reading aloud. She paused to ask students the meaning of the word nature. One student replied "Everything around." Phoebe asked the rest of the students to add more. One student answered "trees" and one student said "animals." Phoebe summarized what students said at the end.

Example 3: Phoebe's reading circle

Phoebe: The author is Douglas Gloria. Let's see it together.

Phoebe: Let's read it together.

Phoebe and Ss: (Read aloud)

Phoebe: What is nature?

S: Everything around

Phoebe: What else can you add?

S: Trees

S: Animals

Phoebe: Things around us that are outside. The grass, trees, birds, animals, things that are outside and around us are part of nature.

S: I know that.

S: It's moving. (Hands wave)

\subsection{Teaching Strategies and Methods}

Station teaching was implemented in John's and Yolanda's classes and these two teachers worked with a small group of students. The learning setting was a little bit different. While students sat around a round table in Yolanda's group, students sat around a semicircle table in John's class. Yolanda held the big book while she taught. John wrote words on the board behind him.

In Yolanda's class, there were four stations including reading comprehension, alphabet, phonics, and sight words. Yolanda was responsible for phonics. She gave students white boards and asked them to write and draw "yam" on the white boards as in Example 4. Sound-it-out was the major method Yolanda used in teaching phonics. 


\section{Macrothink \\ International Journal of English Language Education \\ ISSN 2325-0887 \\ 2013, Vol. 1, No. 1}

Example 4: Yolanda's Draw and Sound-it-Out Exercise

Yolanda: I will give you the board. Can you draw a "yam" and write the word "yam"?

Ss: (Draws a yam and write the word 'yam')

Yolanda: Yours looks really like a yam.

Yolanda: (Point to y-a-m) [y]-[a]-[m]. Let's sound it one more time. [y]-[a]-[m].

There were three stations in John's class: songs, alphabet, and reading comprehension. John was in charge of alphabet and he used sound identification activities in his small group. He asked students to identify the first sound of the word as in Example 5 and students wrote the answer on the white board.

Example 5: John's Exercise on Sound Identification

John: Next word I would you like to hear is "set." What is the first sound you hear?

Ss: (Write "s" on the white board) [s].

John: Do you all agree [s] is the first sound you hear from the word "set"?

John: What is the second sound you hear from "set"?

Ss: [a]

John: What is the third sound you hear from "set"?

Ss: $[\mathrm{t}]$

Both John and Yolanda liked station teaching, because different games, different grouping strategies, and reading groups were used. Both of them had experienced station teaching before this summer school. However, John thought it took time to train students to work effectively in station teaching:

"You can do a lot with stations. Stations can be a good strategy for ELL's, but for kids that are new to school and how school works it will take some time and clear instruction to help understand how groups work and what is expected."

Yolanda also pointed out one problem of station teaching was that a teacher could run out of time.

In Phoebe's class, there was individual work (e.g. ten-minutes free writing, community poster), pair-work (e.g. talk to your partner), group work (e.g. reading circle, puppet show), and whole class activities (e.g. sharing time, grammar instruction). Phoebe taught past tense to the whole class by first saying the present tense of the verb (e.g. eat) and then having the students say the past tense of the verb (e.g. ate) as in Example 6. She also asked students what they did for the weekend and emphasized the past tense of verbs such as "went."

Example 6: Phoebe's Grammar Instruction

Phoebe: I will say the present tense and you will pretend it happen in the past. 
Phoebe: (Point to the poster) Eat

Ss: ate

Phoebe: swim

Ss: swam

Phoebe: What did you do this weekend?

S: I went to a party.

Phoebe: What was the party for?

S: I don't know. My aunt said..... We had crab, meat, pizza.. We ordered pizza. We ate all six.

Phoebe: Did you notice that Tim said "went."

\subsection{Teaching and Supplementary Materials}

A major textbook - National Geographic - with a teacher's manual was used in this summer school as requested by the district office. Yolanda and John all liked the phonics parts of this new curriculum, because it provided what to model and suggested how to use guided practice on phonics. However, John criticized the textbook for not providing sufficient games and additional resources for phonics instruction.

However, both Phoebe and John wondered why they had to use grade level materials below the levels of their students. Phoebe thought it was not rigorous enough: "A question I have is why they gave students content below their grade level? Was that on purpose? If content is easier does that give ELL's more access?"

These three student teachers all agreed that they adapted the curriculum. John mentioned that the markets were the major topic in the curriculum. He adopted the curriculum and taught students how to make change as he described below:

The curriculum talked a lot about markets. One day I observed students struggling with making change out of money. I knew from past experience that in $2^{\text {nd }}$ grade students worked with money and giving change. So I was able to sit down and work with students individually using fake money to help them count through it.

White boards were used in both Yolanda's and John's classes and students were asked to write answers on them. Yolanda also used a big book and flashcards to tell the story and practice phonics. John wrote the word on the board, used the pointer to point to each word and asked students to do sound identification. Picture books, reading books labeled with proficiency levels, posters, paper puppets, and writing journals were the supplementary materials in Phoebe's class.

\subsection{Challenges Student Teachers Faced}

There were two big challenges these student teachers faced when they taught in this summer school. First of all, they did not have much knowledge about the students: no test or academic 
achievement data. Second, because they did not know the major goals of the summer school for these ELL students they did not know how to best scaffold their learning.

\section{Discussion}

Three major findings can be expressed for this study. First, there were no clear goals for the summer school, so the three student teachers did not know what they were expected to help the ELLs to achieve. All they could do was to expose the ELLs to English through phonics, reading, writing, and task-based activities. In effective instruction, concrete content objectives that identify what students should know and be able to do must guide teaching and learning (Echevarria, Vogt, \& Short, 2008). In addition to content objectives, Echevarria et al (2008) further state that language objectives must be clearly defined, displayed, and reviewed with students. Language objectives may cover a range from process-oriented to performance-oriented statements so that students have a chance to explore, and then practice before demonstrating mastery of an objective.

Second, because no information about the ELLs' academic background was provided to the teachers they did not know their true English proficiency or content knowledge. All they knew was their grade levels. The teachers could not adapt the content to make it appropriate to the ELLs' proficiency levels.

Third, these three student teachers used different teaching activities and language foci in the summer school. The class instruction, language foci, teaching and supplementary materials were similar in John and Yolanda's class, because John and Yolanda taught lower grades. Both of the classes focused on phonics and they implemented station teaching in their classrooms. White boards and markers were used a lot in phonics and alphabet instruction. Phoebe taught middle and higher grade levels, so the class instruction, language foci, teaching and supplementary materials were different from the lower grade levels. Reading and writing were the major foci in the class. Individual student work, pair work, group work, and whole-class instruction were carried out in Phoebe's classes. However, these three student teachers did not use any technology such as computer in the summer school program. Using multimedia in remedial education can provide students alternative ways to learn (Chen, 2005; Liao, 2007; Lin, 2007).

In order to more effectively implement a summer school program, three suggestions are provided. First of all, orientation and professional development should be provided for teachers before the summer school begins. The professional development should cover such topics as the goals of the summer school, curriculum, standards, and ELL teaching strategies, so teachers will be familiar with what the objectives of the summer school are and how they should teach in order to meet the objectives. Second, students' data including academic performance, English proficiency levels, educational background in home country, etc should be provided, to give the teachers a better understanding of the students' backgrounds. A pre-assessment and post-assessment should be carried out to check whether the summer school instruction positively influences students' academic performance and what further instruction can be provided. Third, technology or computer-assisted language learning should be used in this summer school. Learners can listen to the CDs provided by the textbook 
publishers to review the lessons or do the interactive exercises on the computer. In addition, a lot of online interactive web sites can be used.

\section{Conclusion}

Disadvantaged students such as ELLs need additional education and support to help them keep up with their English speaking peers. A summer school program was designed and provided for ELLs in a school district in a US northwest city in 2010 and aimed to bridge the achievement gap. Based on the data analysis of interviews, documents, and classroom observations, three major findings were made: the unclear goals of the summer school, the limited information the teachers had about the ELLs, and varying teaching activities and language foci. Three suggestions about how to effectively implement summer school classes: the provision of orientation on the summer school to teachers, access to information about students' backgrounds, and the integration of technology.

This study focuses only on the teachers' perspective of the summer school in terms of goals and language foci, teaching strategies and methods, teaching and supplementary materials, and the challenges they faced. Another study could focus on the attitudes of administrators and students toward the summer school so as to understand how summer schools can be operated more effectively. Further research could compare and contrast students' standardized test performance before and after summer school to examine whether summer school positively influences students' learning and academic performance.

\section{References}

Ajwani, S. (2006). The success of educational interventions in grades three and five in improving academic progress. (Unpublished doctoral dissertation). St. John's University, New York.

Ashdown, J., \& Simic, O. (2000). Is early literacy intervention effective for English language learners? Evidence from Reading Recovery. Literacy Teaching and Learning, 5(1), 27-42.

Bartels, N. (2005). Researching applied linguistics in language teacher education. In Bartels, N. (Ed.), Applied linguistics and language teacher education. New York, NY: Springer Science and Business Media, Inc.

Blaikie, N. (2000). Designing social research. Cambridge, UK: Polity Press.

Borman, G. (2001). Summers are for learning. Principal, 80(3), 27-29.

Chen, Y. C. (2005). A study of integrating multimedia into English remedial instruction for EFL elementary school underachievers. (Unpublished master's thesis). National Chung Cheng University, Chiayi County, Taiwan.

Cooper, H., Charlton, K., Valentine, J. C., Muhlenbruck, L., \& Borman, G. D. (2000). Making the most of summer school. Monographs of the Society for Research in Child Development, 65(1), 18-109.

Council of the Great City Schools. (2008). Raising the achievement of English language 


\section{Macrothink}

International Journal of English Language Education

ISSN 2325-0887

2013, Vol. 1, No. 1

learners in the Seattle public schools. Seattle, WA: Council of the Great City Schools.

Creswell, J. W. (2009). Research design: Qualitative, quantitative, and mixed methods approach $\left(3^{\text {rd }}\right.$ ed.). Thousand Oaks, CA: Sage Publications.

Echevarria, J., Vogt, M., \& Short, D. (2008). Making content comprehensible for English learners: The SIOP model. Boston, MA: Pearson Education, Inc.

Flick, U. (1998). An introduction to qualitative research. Thousand Oaks, CA: Sage Publications.

Hammersley, M., \& Atkinson, P. (1983). Ethnography. Principles in practice. New York, NY: Humanities Press.

Hatch, J. A. (2002). Doing qualitative research in education settings. Albany, NY: State University of New York Press.

Hitchcook, G., \& Hughes, D. (1989). Research and the teacher: A qualitative introduction to school-based research. New York, NY: Humanities Press.

LeCompte, M. D., \& Schensul, J. J. (1999). Designing and conducting ethnographic research. Walnut Creek, CA: AltaMira.

Liao, H. P. (2005). A case study of the effects of the language experience approach as a remedial program on an EFL elementary low achiever's vocabulary power. (Unpublished master's degree thesis). Tamkang University, Taipei County, Taiwan.

Lin, P. J. (2007). The study of integrating computer-assisted cooperative learning into English remedial instruction for elementary school underachievers. (Unpublished master's thesis). National Chiayi University, Chiayi County, Taiwan.

Luftig, R. (2003). When a little bit means a lot: The effects of a short-term reading program on economically disadvantaged elementary schoolers. Reading Research and Instruction, 42(4), 1-13. http://www.tandfonline.com/doi/abs/10.1080/19388070309558393\#preview

Marshall, C., \& Rossman, G. B. (2006). Design qualitative research ( $4^{\text {th }}$ ed.). Thousand Oaks, CA: Sage Publications.

Moore, M., \& Wade, B. (1998). Reading Recovery: Its effectiveness in the long term. Support for Learning, 13(3), 123-128. http://onlinelibrary.wiley.com/doi/10.1111/1467-9604.00073 /abstract

Richards, L., \& Morse, J. M. (2007). Readme first for a user's guide to qualitative methods. Thousand Oaks, CA: Sage Publications.

Southern Regional Educational Board. (2002). Summer school: Unfulfilled promise. Atlanta, GA: Author.

U. S. Department of Education, National Center for Education Statistics. (2006). The condition of education 2006 (NCES2006-071). Washington, DC: U.S. Government Printing Office. 


\section{Macrothink}

International Journal of English Language Education ISSN 2325-0887 2013, Vol. 1, No. 1

Ziegler, L. K. (2000). A descriptive study of a Title I summer school program for primary age children. (Unpublished doctoral dissertation). University of Pittsburg, Pennsylvania.

\section{Copyright Disclaimer}

Copyright reserved by the author(s).

This article is an open-access article distributed under the terms and conditions of the Creative Commons Attribution license (http://creativecommons.org/licenses/by/3.0/). 